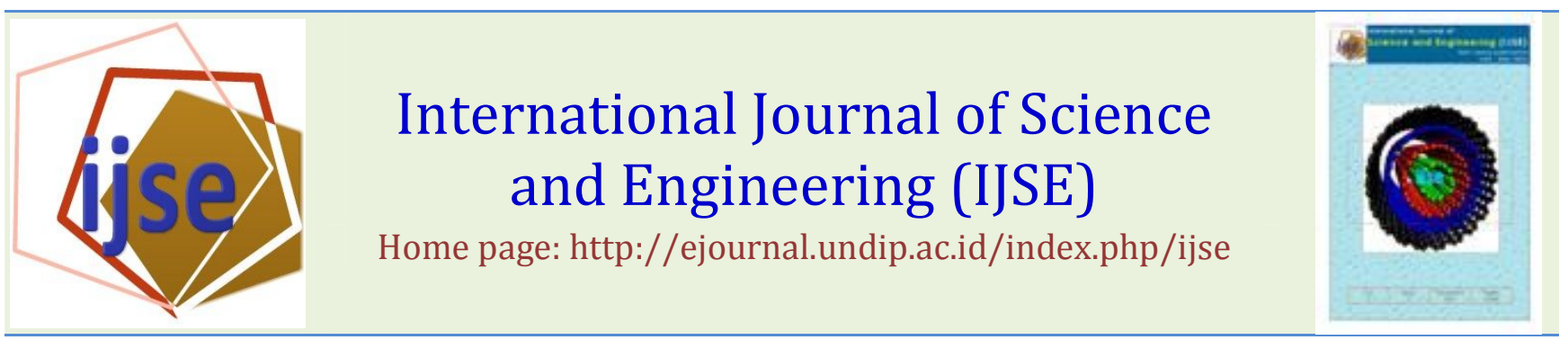

\title{
Zinc Supplementation Dosage Variations to Metallothionein Protein Level of Rattus norvegicus
}

\author{
Budi Santosa ${ }^{1}$, Hertanto W.S 2 , Lisyani S ${ }^{3}$. Henna R.S ${ }^{4}$ \\ Student PhD of Medicine/Health ${ }^{1}$, Department of Nutrition Consultant ${ }^{2}$, Department of Clinical Patology Consultant ${ }^{3}$, \\ Department of Pharmacy 4 , Diponegoro University of Semarang \\ Permanent address: ${ }^{1}$ Health Analyst of Nursing and Health Faculty of \\ Muhammadiyah University, Semarang
}

e-mail:1 budi_unimus@yahoo.co.id; 2hertantow@gmail.com; ${ }^{3}$ lisyani_s@yahoo.com;4hennarsunoko@gmail.com

\begin{abstract}
Zinc is an essential trace element involving in the activity of more than 300 enzymes and proteins of human body. One important role of zinc is to improve metallothionein protein binding heavy metals and functioning as heavy metal detoxification facilities. This research discusses the effect of zinc supplement on the improvement of metallothionein protein level. The in vivo test involving 28 rats categorized in 4 groups was performed. The experiments used randomized post test control group design. The 3 groups were daily supplemented by zinc in th concentration of $0.2 \mathrm{mg}, 0.4 \mathrm{mg}$, and $0.8 \mathrm{mg}$. Whereas, the last group was let without zinc treatment. As an indicator the metallothionein protein level was checked after three weeks. The data was then evaluated by Anova an Bonferroni test in order to know the signicant of protein level difference among the groups.

The result showed that the average of metallothionein protein level improved by increasing zinc suppplement with the $0.95 \pm 0.20 ; 1.28$ $\pm 0.19 ; 1.39 \pm 0.09 ; 1.91 \pm 0.3 \mathrm{ng} / \mathrm{ml}$ metallothionein per 0, 0,2, 0,4, 0,8.mg zinc added. Based on the ANOVA and Bonferroni test, indicated that the improvement was significant as shown with $p$ value of 0.00

Key Words - Zinc supplementation, metallothionein.
\end{abstract}

Submission: August 24, $2013 \quad$ Corrected : September 13, 2013 Accepted: September 19,2013

Doi: http://dx.doi.org/10.12777/ijse.5.2.15-17

[How to cite this article: Santosa, B., Hertanto, W.S, Lisyani, S. Henna, R.S. (2013). Zinc Supplementation Dosage Variations to Metallothionein Protein Level of Rattus norvegicus. International Journal of Science and Engineering, 5(2),9-14. Doi: http://dx.doi.org/10.12777/ijse.5.2.15-17]

\section{INTRODUCTION}

Metallothionein was firstly discovered in 1957 as protein containing a large amount of sulphur and having a close relationship with zinc. There was significant positive correlation between zinc and Metallothionein at any ages.(Blalock et al.,1988; Berdanier 1998; Lee et al,. 2013).

Metallothionein is a protein (polypeptide) having small molecular mass ( $4-8 \mathrm{kDa})$, containing cysteine amino acid (Cys), but having no aromatic amino acid or histidine. The classification of Metallothionein is based on the composition of amino acid, number and division of Cys-amino in sequence, and the similarity of phylogenic sequence and relationship. Metallothionein is not only found in any levels of tissues and organs but also in cytoplasm and nucleus (Steven et al.,2000)
The role of metallothionein in metal detoxification mechanism deals with the ability of metallothionein to bind toxic metals. Metallothionein is metal-binding protein functioning in the process of binding or locking up metals in tissues of every living thing. Thus, metallothionein can be used as indicator upon metal contamination. (Cheung et al., 2001; Jiang et al ., 2013).

Metallothionein has the ability to bind metals strongly as it contains a large number of "thiol" groups (sulfidril, SH). The sulfide residue of Cys is able to bind metal ions of two or three SH residues. The binding coordination of each metal ion of Cys forms the structure of tetrahedral tetrathiolate. Cys residue is needed to detoxify heavy metal by binding the 
transitional metal cations. (Cheung et al., 2001; Jiang et al ., 2013).

The research conducted by Sulivan using ELISA method showed the relationship between zinc supplementation and metallothionein protein level. Zinc supplementation of 50 $\mathrm{mg} /$ day to male adults improved the erythrocyte and monosyte metallothionein protein.( Sullivan et al., 1998).

Considerations upon the decision of zinc supplementation method procurement were the solubility, bioavailability, taste, side effect, and dosage frequency (Brown et al., 2002). An informal survey of zinc supplementation showed that one of the basic considerations to use the zinc supplementation form was the taste. Zinc citrate taste with the dosage of $3 \mathrm{mg}$ could not be accepted although in orange juice. Zinc sulphate and glutamate with the dosage of 10-20 mg was acceptable taste. (Allen 1998).

Zinc absorption or supplementation of food intake ranged from 15-60\%. Zinc dosage between 5-20mg per day was mostly used in many researches for observing the influence of zinc to growth. Meta-analysis supplementation used the dosage of 1.5-50 mg per day with consideration to the number of materials inhibiting the absorption level. Zinc gradual supplementation dosage activity to improve metallothionein protein considers important aspects such as $10 \mathrm{mg}$ per day, $20 \mathrm{mg}$ per day, and $40 \mathrm{mg}$ per day. Those dosages have to be proportionally converted due to the animals used in experiment. For examples, the dosage of 10 $\mathrm{mg}, 20 \mathrm{mg}$, and $40 \mathrm{mg}$ were converted into $0.2,0.4$, and 0.8 respectively (Donatus 1994). Zinc supplementation with the appropriate dosage must be analyzed as the preventive effort to heavy metal toxicity.

\section{MATERIAL AND METHOD}

This research used experimental method with Randomized post test only control-group design. The ethical clearance had been approved by the ethics commission of the medical faculty of Diponegoro University / Dr. Kariadi Hospital of Semarang No. 339/EC/FK/RSDK/2012 of October $18^{\text {th }}, 2012$. The samples taken from LPPT UGM were 28 male rats called Rattus norvegicus, with 15 weeks old, and 180-220 gram weight. Those 28 rats were divided into 4 groups: 1 control and 3 treatment groups. Starting from the first to the third weeks, the treatment groups were gradually supplemented with $0.2 \mathrm{mg}, 0.4 \mathrm{mg}$, and $0.8 \mathrm{mg}$ of zinc per day, while the control group is not supplemented with zinc. At the end of third week, the metallothionein protein level in all groups was checked. The results were evaluated using one way Anova test followed by Bonferroni test in order to know the sginificant effect of the treatment.

\section{RESULTS AND DISCUSSION}

\section{Metallothionein Level}

Metallothionein levels of those control and treatment groups were checked in the third week. The average and trend of Metallothionein levels could be seen in table 1 and Fig. 1 below.

Table 1. The Average of Metallothionein level of Control and Treatment Groups

\begin{tabular}{clc}
\hline & \multicolumn{2}{c}{ Metallothionein Level } \\
\cline { 2 - 3 } Group & Average $(\mathrm{ng} / \mathrm{ml})$ & $p$ \\
\hline KC & $0.95 \pm 0.20$ & 0.00 \\
KP1 & $1.28 \pm 0.19$ & \\
KP2 & $1.39 \pm 0.09$ & \\
KP3 & $1.91 \pm 0.32$ & \\
\hline
\end{tabular}

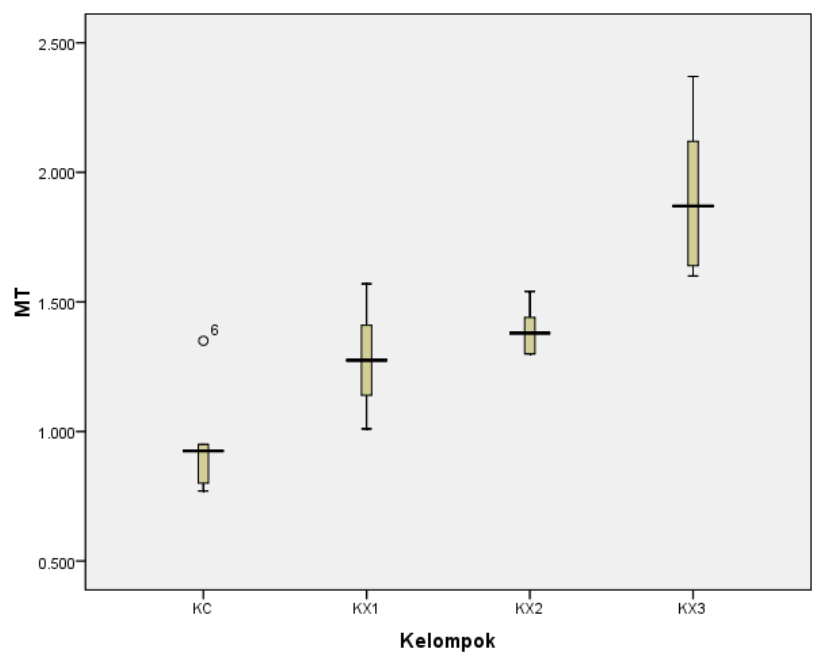

Fig 1. Picture of Metallothionein level differences Group KC, KX1, KX2, KX3

Table. 2. Bonferroni test upon Metallothionein level of Control and Treatment Groups

\begin{tabular}{ccc}
\hline Parameter & $\begin{array}{c}\text { Average } \\
\text { Difference }\end{array}$ & $p$ \\
\hline MT KC with KP1 & 0.32 & 0.11 \\
MT KC with KP2 & 0.43 & 0.16 \\
MT KC with KP3 & 0.95 & 0.00 \\
\hline
\end{tabular}

Table 1 and Fig 1 showed that the unsupplemented rats of control group had the lowest Metallothionein level. Meanwhile the zinc-supplemented rats improved significantly. The higher dosage, the higher Metallothionein level. Here, wiith the zinc supplementation of $0.8 \mathrm{mg}$ (KX3), the Metallothionein level was $1.91 \mathrm{ng} / \mathrm{ml}( \pm 0.32)$. The ANOVA test showed the value of $p=0.00$ and then followed by Bonferroni test (table 2) resulting in significant difference of control and zinc-supplemented treatment group of $0.8 \mathrm{mg}$ (KX3) with the value of $p=0.00$.

Metallothionein level improved in accordance with zinc supplementation improvement. The zinc supplementation of $0.2 \mathrm{mg}, 0.4 \mathrm{mg}$, and $0.8 \mathrm{mg}$ had the average of metallothionein of $1.28 \mathrm{ng} / \mathrm{ml}, 1.39 \mathrm{ng} / \mathrm{ml}$, and $1.91 \mathrm{ng} / \mathrm{ml}$ respectively. These showed that the improvement of zinc 
dosage supplementation is followed by the improvement of metallothionein protein level.

Supporting the research conducted by Sullivan et al. (1998) that zinc supplementation of $50 \mathrm{mg}$ daily given to adult might improved erythrocyte and monocyte metallothionein protein. His research aimed to examine metallothionein gene transcription based on zinc index status to human after zinc supplementation. The method used enzyme linked immunoassay (ELISA) with sandwich approach. The monoclonal antibody was used to compare the level of erythrocyte metallothionein protein with the level of moncyte mRNA metallothionein. This aspect was measured using polymerase chain reaction (PCR) during zinc supplementation. 25 adult subjects of 19 to 35 years old were supplemented with zinc of $50 \mathrm{mg} /$ day for 18 days while the control subjects were given placebo. The erythrocyte metallothionein protein level improved significantly in 8 days compared to the control subjects. The monocyte mRNA metallothionein protein level improved significantly in 2 days compared to control subjects. Zinc concentration plasma was significantly higher than control subjects in 6 days after zinc supplementation.

The research conducted by Aydemir TB et al, (2005) supported that zinc supplementation improved metallothionein protein. The research was conducted with male adult subjects of 19 to 31 years old. Zinc (ZnSO4) of 15 $\mathrm{mg} /$ day was supplemented to treatment groups while placebo was given to control group. The metallothionein protein levels of the treatment groups improved better than the control one.

Metallothionein expression had promised as potential index of zinc status to animal and human. Blalock et al, (1988), Villalobos AR and Young RK, (2011) showed that mRNA expressions of livers, intestines, and kidneys were regulated by zinc intake. The metallothionein protein level in serum/plasma and erythrocyte of rats had been proven having good correlation with zinc intake. Zlotkin SH,(1988) stated that there was significant positive correlation between zinc and metallothionein at any ages. Gallant KR et al. (1987) said that metallothionein concentration of livers was directly regulated by zinc diet status, high concentration of high zinc diet, and low concentration of low zinc diet. ELISA Method could be used to know the concentration of metallothionein protein during zinc diet. This method was the initial effort to assess the zinc status based on the concentration of metallothionein protein during zinc supplementation.

This research showed that metallothionein protein concentration could be regulated by zinc supplementation. metallothionein is protein (polipeptida) having small molecular mass and containing a great number of "thiol" groups as its main characteristic, $26-33 \%$ of cysteine amino acid (Cys), but having no aromatic amino acid or histidine (Cheung et al., 2001; Zlotkin et al., 2013).

\section{CONCLUSION}

The average of metallothionein level improved with the increase of zinc dosage supplementation. The highest methalothionein level of $1.91 \mathrm{ng} / \mathrm{ml}$ was reached with 0.8 zinc supplementation. Based on the statistical test, there was significant difference of metallothionein level between control and treatment group which was zinc-supplemented of $0.8 \mathrm{mg}$, with the value of $p=0.00$.

\section{ACKNOWLEDGMENT}

The research was conducted in laboratory of Biomedic Muhammadiyah University, Semarang and LPPT of Gadja Mada University, Yogyakarta.

\section{REFERENCES}

1. Allen,L.H., (1998). Zinc and Micronutrient Suplement for Children. Am J Clin Nutr.;68:495S-8S

2. Aydemir, T.B., Raymond, K.B., Cousins, R.J. (2005). Zinc supplementation of young men alters metallothionein, zinc transporter, and cytokine gene expression in leukocyte populations. Nutritional Genomics Laboratory, Food Science and Human Nutrition Department, Center for Nutritional Sciences, University of Florida, Gainesville;FL 32611-0370

3. Berdanier, C.D. (1998). Advanced nutricion micronutrients. New York: CRC Press.;183-203.

4. Blalock, T.L., Dunn,M.A., \& Cousins, R. J. (1988). Metallothionein gene expression in rats: tissue-specific regulation by dietary copper and zinc. J. Nutr.;118: 222-8.

5. Brown, K.H., Peerson, J.m., Rivera, J., Allen, L.H. (2002). Effect of Suplementation zinc on the growth and serum zinc concentration of pre pubertal children: a meta analysis of randomized controlled trials. Am J Clin Nutr.;75:1062-71.

6. Cheung, R.C.K., Chan, M.H.M., Lam, C.W.K., and Lau, E.L.K., (2001). Heavy metal poisoning clinical significance and laboratory investigation.Asia pasific Analyte Notes. BD Indispensable to Human Health. Hong Kong.; $7(1): 22-34$

7. Donatus, I.A., (1994). Petunjuk Praktikum Toksikologi. Edisi I. Yogyakarta: Lab. Farmakologi dan Toksikologi. Fakultas Farmasi Universitas Gadjah Mada.;21-2

8. Gallant, K.R., Cherian, G. (1987).Changes in Dietary Zinc Result in Specific Alterations of Metallothionein Concentrations in Newborn Rat Liver. The Journal of Nutrition.;117:709-16.

9. Jiang, S., Rui Guo., Zhang, Y., Zou, Y., and Ren, J. (2013). Heavy metal scavenger metallothionein mitigates deep hypothermia-induced myocardial contractile anomalies: role of autophagy.Am J Physiol Endocrinol Metab.; 304: 74 - 86.

10. Lee, S.M., McLaughlin, J.N., Frederick, D.R., Zhu, L., Thambiayya, K., Wasserloos, K.J. (2013). Metallothionein-induced zinc partitioning exacerbates hyperoxic acute lung injury. Am J of Physiology - Lung Cellular and Molecular Physiology:;304: 350-60.

11. Steven, R., Davis and Cousin, J.R. (2000). Metallothionein Expression in Animal: A Physiological Perspective on Function. American Society for Nutrition Sciences, Food Science and Human Nutrition Departement, University of Florida, Gainesville FL.; 32611-0370.

12. Sullivan, V.K., Burnett, F.R., and Cousins, R.J. (1998). Metallothionein Expression is Increased in Monocytes and Erythrocytes of Young Men during Zinc Suplementation. J. Nutr.;128:703-7

13. Villalobos, A.R., and Young, R.K. (2011). Metallothionein (MT-1) siRNA compromises the efficacy of $\mathrm{Zn}$ to ameliorate stress-modulation of choline transport in choroid plexus. FASEB J.; 25(3): 838.

14. Zlotkin, S.H., Cherian, M.G.,(1988). Hepatic metallothionein as a source of zinc and cysteine during the first year of life. Pediatr Res. ;24(3):326329 